\title{
EFFECT OF WATER EXTRACT OF PLANTS CONTAINING TANNIN ON IN VITRO METHAGONESIS AND FERMENTATION CHARACTERISTICS OF THE GRASS Pennisetum purpureophoides
}

\author{
B. Santoso, E. W. Saragih and B. Tj. Hariadi \\ Department of Animal Nutrition, Faculty of Animal Science, Fishery and Marine Science, \\ State University of Papua, Manokwari 98314, Papua Barat - Indonesia \\ Corresponding E-mail: santosob@lycos.com
}

Received January 08, 2013; Accepted February 20, 2013

\begin{abstract}
ABSTRAK
Penelitian ini dilaksanakan untuk mengevaluasi pengaruh perbedaan ekstrak tanaman yang mengandung tanin terhadap produksi $\mathrm{CH}_{4}$, karakteristik fermentasi dan degradasi nutrien secara in vitro. Enam jenis daun tanaman yaitu Gliricidia sepium, Acacia mangium, Leucaena leucocephala, Desmodium intortum, Camellia sinensis, Calliandra calothyrsus dan biji Areca catechu diekstraksi menggunakan pelarut air. Perlakuan percobaan terdiri atas $P$. purpureophoides $(300 \pm 5 \mathrm{mg})$ diinkubasi tunggal atau ditambah 1,2 mL ekstrak tanaman. Degradasi NDF diukur menggunakan prosedur Tilley and Terry tahap pertama. Hasil penelitian menunjukkan bahwa konsentrasi tanin total pada ekstrak tanaman bervariasi antara $34-95 \mathrm{~g} / \mathrm{kg} \mathrm{BK}$, terendah pada $D$. intortum dan tertinggi pada A. mangium. Produksi $\mathrm{CH}_{4}$ pada inkubasi 48 jam signifikan lebih rendah $(\mathrm{P}<0,001)$ dengan penambahan ekstrak $A$. mangium, L. leucocephala, A. catechu, $C$. sinensis dan C. calothyrsus dibandingkan kontrol. Tanin total mempunyai hubungan yang erat dengan produksi $\mathrm{CH}_{4}(r=-0,79)$. Terdapat korelasi yang kuat antara produksi $\mathrm{CH}_{4}$ dan konsentrasi NDF $(r=0,61)$. Disimpulkan bahwa ekstrak tanaman A. mangium, $L$. leucocephala, A. catechu, C. sinensis dan C. calothyrsus menggunakan air berpotensi sebagai manipulator untuk menurunkan produksi $\mathrm{CH}_{4}$ pada ternak ruminansia.
\end{abstract}

Kata kunci: in vitro, metana, ruminansia, tanin, ekstrak

\begin{abstract}
This experiment was conducted to evaluate the effect of extract of plants containing tannin on in vitro $\mathrm{CH}_{4}$ production, fermentation characteristics and nutrient degradability. Six of plant leaves i.e. Gliricidia sepium, Acacia mangium, Leucaena leucocephala, Desmodium intortum, Camellia sinensis, Calliandra calothyrsus and seed of Areca catechu were extracted by using water. Experimental treatments consisted of $P$. purpureophoides $(300 \pm 5 \mathrm{mg})$ incubated alone or added with $1.2 \mathrm{~mL}$ of plant extracts. The in vitro neutral detergent fibre (NDF) degradability was determined using the first stage technique of Tilley and Terry. The results showed that total tannin concentration of plant extract ranged from 34 to $95 \mathrm{~g} / \mathrm{kg} \mathrm{DM}$, and was lowest in D. intortum and highest in A. mangium. Methane production was significantly $(\mathrm{P}<0.001)$ lower with addition of A. mangium, L. leucocephala, A. catechu, C. sinensis and $C$. calothyrsus extracts compared to control. Total tannin had a close relationship with $\mathrm{CH}_{4}$ production $(r=-0.79)$. There was strong correlation between $\mathrm{CH}_{4}$ production and NDF degradability $(r=0.61)$. It was concluded that water extracts of A. mangium, L. leucocephala, A. catechu, $C$. sinensis and $C$. calothyrsus have potential to be used as rumen manipulator in order to reduce $\mathrm{CH}_{4}$ production in ruminants.
\end{abstract}

Keywords: in vitro, methane, ruminant, tannin, extract

\section{INTRODUCTION}

Methane $\left(\mathrm{CH}_{4}\right)$ is produced as a result of anaerobic fermentation of the soluble and structural carbohydrates by methanogens in the rumen of ruminant animals, which is released into the environment by eructation. The $\mathrm{CH}_{4}$ emissions from ruminant animals range from 2 to $12 \%$ of the gross energy intake (Johnson and Johnson, 1995). Besides, it has been estimated that the world's population of ruminants produce about $15 \%$ of total atmospheric $\mathrm{CH}_{4}$ emissions 
(Moss, 1993). This means that $\mathrm{CH}_{4}$ production from ruminant is not only represents a substantial loss in efficiency of animal production, but also contributes significantly to global warming as the greenhouse gas.

Recently, there is an increasing interest in research activities to evaluate the potential of secondary plant compound as feed additives instead of chemical compounds i.e. ionophores and antibiotics as manipulators of rumen fermentation including decrease $\mathrm{CH}_{4}$ production. As previously stated by Russell and Rychlik (2001), there has been an increased perception that antibiotics and chemical compounds should not be routinely used as feed additives.

Tannin is a phenolic plant secondary compound and is widely distributed through plant kingdom especially legume and browse. Makkar et al. (1995) noted that secondary compound tannin is prevalent in many tropical fodder plants. Effect of tannin from some plants such Acacia mangium, Biophytum petersianum and Psidium guajava has been demonstrated as supplement to the tropical grass Pennisetum purpureum (Hariadi and Santoso, 2010). Plant extract containing tannin have been shown to decrease $\mathrm{CH}_{4}$ production (Śliwiński et al., 2002; Sirohi et al., 2009) and ruminal NDF digestibility (McSweeney et al., 2001; Oliveira et al., 2007). Previous study with tropical plants, Jayanegara et al. (2011) concluded that total tannin had close relationship with $\mathrm{CH}_{4} /$ digestible OM ( $\left.r=-0.74\right)$. However, use of water as a solvent is more applicable and safe for animals than chemical solvents i.e. methanol, ethanol or acetone. The objective of this study was to evaluate the effect of water extracts from plant containing tannin on in vitro $\mathrm{CH}_{4}$ production, fermentation characteristics, and nutrient degradability.

\section{MATERIALS AND METHODS}

\section{Samples and Extract Preparations}

King grass (P. purpureophoides) was planted in a $6 \mathrm{~m}^{2}$ plot without fertilizer at the Animal Research Station of State University of Papua in Manokwari. Grass was harvested after 50 days, chopped to $5 \mathrm{~cm}$ in length and oven-dried at $60^{\circ} \mathrm{C}$ for $48 \mathrm{~h}$.

The leaves of G. sepium, A. mangium, $L$. leucocephala, $C$. sinensis, D. intortum and $C$. calothyrsus and seed of A. catechu were collected from the Manokwari Regency. The collected samples were then pooled and oven-dried at $60^{\circ} \mathrm{C}$ for $48 \mathrm{~h}$. A commercial leaf of $C$. sinensis was used in this experiment. Samples of grass, leaves and seed of plants were ground to pass a $1 \mathrm{~mm}$ sieve in a Wiley mill.

Plants extract were prepared in water following a modified method of Patra et al. (2006). About $5 \mathrm{~g}$ of finely ground plants material were weighed into $100 \mathrm{ml}$ beaker glass and added $50 \mathrm{ml}$ of water. Plant materials were boiled for 10 min on a hotplate. The beakers were stoppered and incubated at $39^{\circ} \mathrm{C}$ on a shaker for $24 \mathrm{~h}$ and filtered through 2 layers of cheesecloth. The filtrates were stored at $4^{\circ} \mathrm{C}$ for further use.

\section{Experimental Design and Treatments}

The experiment was arranged in a completely randomized design with eight treatments and three replications. Experimental treatments consisted of $P$. purpureophoides incubated alone as control or added with plant extract at level of $1.2 \mathrm{~mL} / 300 \mathrm{mg}$ of substrate.

\section{In vitro $\mathrm{CH}_{4}$ Production and Nutrient Degradability Measurements}

The in vitro gas production method was essentially according to Menke and Steingass (1988) as previously demonstrated by Hariadi and Santoso (2010). Oven-dried samples of about $300 \pm 5 \mathrm{mg}$ were weighed into $100 \mathrm{~mL}$ glass syringes with pistons lubricated with Vaseline. Rumen liquor was obtained from two ruminally fistulated Holstein Frisian cross-bred cows fed elephant grass twice a day at maintenance level. About $30 \mathrm{~mL}$ of rumen liquor-buffer mixtures (1: 2 , v/v) was added into each syringe and then incubated in a water bath at $39^{\circ} \mathrm{C}$ for $48 \mathrm{~h}$. The volume of gas released from each syringe was recorded before incubation $(0 \mathrm{~h})$ and $2,4,6,12$, 24 and $48 \mathrm{~h}$ of incubation.

Ten milliliter of gas was collected at 24 and $48 \mathrm{~h}$ of incubation from the silicon tube at the syringe tip using Terumo syringe and pooled to vacutainer tube for $\mathrm{CH}_{4}$ analysis. Methane was determined by injection $100 \mathrm{~mL}$ of gas into a chromatograph gas. The volume of $\mathrm{CH}_{4}$ production was calculated by using formula: $\mathrm{CH}_{4}$ production $(\mathrm{ml})=$ total gas produced $(\mathrm{ml}) \times \%$ $\mathrm{CH}_{4}$ in the sample.

At the end of the incubation period, about $10 \mathrm{ml}$ of syringe contents were sampled. The $\mathrm{pH}$ of medium incubation was recorded using a digital $\mathrm{pH}$ meter. Subsequently, $0.2 \mathrm{~mL}$ of sub- 
samples were pipetted into $1.5 \mathrm{~mL}$ micro centrifuge tube containing $1 \mathrm{ml}$ of $25 \mathrm{~g} / 100 \mathrm{~mL}$ (w/v) metaphosphoric acid and centrifuged at $9000 \times g$ for $10 \mathrm{~min}$ for volatile fatty acids (VFA) determination. Further on $2 \mathrm{~mL}$ of sub-samples were added to $2 \mathrm{~mL}$ of $20 \mathrm{~g} / \mathrm{l}(\mathrm{w} / \mathrm{v}) \mathrm{NaCl}$ for $\mathrm{NH}_{3}$ N (Chaney and Marbach, 1962).

The in vitro organic matter (OM) and NDF degradability was determined using the first-stage technique as proposed by Tilley and Terry (1963) as previously demonstrated by Hariadi and Santoso (2010).

\section{Laboratory Analyses}

Dried samples were used to determine DM, ash and crude protein (CP) according to procedure of AOAC (1990). Total tannin and condensed tannin contents were assayed using FolinCiocalteu and butanol- $\mathrm{HCl}$ methods respectively (Makkar, 2003). Concentrations of NDF and acid detergent fibre (ADF) were determined following Van Soest et al. (1991).

\section{Statistical Analysis}

Data was analyzed using the procedure GLM of SAS (version 6.12, SAS institute, Cary, NC, USA). Duncan's multiple range test was used to separate treatment means. Correlation analysis was done to establish the relationship between variables.

\section{RESULTS AND DISCUSSION}

\section{Results \\ Chemical Composition of Plants}

The chemical composition of experimental plants is presented in Table 1. The NDF and ADF content in plants containing tannin ranging from 269 to 596 and 115 to $381 \mathrm{~g} / \mathrm{kg} \mathrm{DM}$, respectively. The ranking order of plant samples on the basis their total tannin content was $A$. mangium $>C$. calothyrsus $\langle$ L. leucocephala $\langle$ A. catechu $>C$. sinensis $>G$. sepium $>D$. intortum. However, on the basis of their condensed tannin concentration the plant could be ranked as A. mangium $>A$. catechu > L. leucocephala > G. sepium > C.calothyrsus $>$ C.sinensis $>$ D. intortum.

\section{In vitro Gas and $\mathrm{CH}_{4}$ Productions}

Effect of plant extract containing tannin on gas and $\mathrm{CH}_{4}$ production are given in Table 2. Gas production was significantly $(\mathrm{P}<0.001)$ different among treatments at 6,24 and $48 \mathrm{~h}$ of incubation. Addition of plant extracts in grass substrate decreased $(\mathrm{P}<0.001)$ gas production at $48 \mathrm{~h}$ of incubation compared to control. Methane production in substrate with addition of $A$. mangium, L. leucocephala, A. catechu, $C$. sinensis and $C$. calothyrsus extracts was significantly $(\mathrm{P}<0.001)$ lower as compared to control. The $\mathrm{CH}_{4}$ produced at $48 \mathrm{~h}$ of incubation averaged $12.3 \%$ of total gas at $48 \mathrm{~h}$ of incubation.

Table 1. Chemical Composition (g/kg DM) of P. purpureophoides Incubated as Substrate, and Leaves or Seed Plant Containing Tannin

\begin{tabular}{lccccccc}
\hline & OM & CP & NDF & ADF & $\begin{array}{c}\text { Hemi- } \\
\text { celullose }\end{array}$ & TT & CT \\
\hline P. purpureophoides & 953 & 148 & 751 & 404 & 347 & 5 & N.D. \\
G. sepium & 916 & 219 & 466 & 315 & 261 & 45 & 25 \\
A. mangium & 934 & 241 & 477 & 216 & 261 & 95 & 36 \\
L. leucocephala & 920 & 344 & 269 & 115 & 154 & 81 & 28 \\
A. catecú & 975 & 102 & 496 & 135 & 361 & 77 & 35 \\
D. intortum & 881 & 207 & 403 & 209 & 194 & 34 & 5 \\
C. sinensis & 936 & 197 & 424 & 269 & 155 & 69 & 20 \\
C. calothyrsus & 944 & 188 & 596 & 381 & 215 & 82 & 21 \\
\hline DM & & & & &
\end{tabular}

$\mathrm{DM}=$ dry matter; $\mathrm{OM}=$ organic matter $; \mathrm{CP}=$ crude protein; $\mathrm{NDF}=$ neutral detergent fiber; $\mathrm{ADF}=$ acid detergent fiber; $\mathrm{TT}=$ total tannin; $\mathrm{CT}=$ condensed tannin; $\mathrm{ND}=$ not detected 
Table 2. Gas and $\mathrm{CH}_{4}$ Productions of in vitro Incubation of P. purpureophoides Alone or with Addition of Plant Extracts

\begin{tabular}{|c|c|c|c|c|c|}
\hline & \multicolumn{3}{|c|}{ Total gas $(\mathrm{ml} / 300 \mathrm{mg}$ of $\mathrm{DM})$} & \multirow{2}{*}{$\begin{array}{c}\mathrm{CH}_{4} \\
(\mathrm{ml} / 300 \mathrm{mg} \text { of } \mathrm{DM})\end{array}$} & \multirow{2}{*}{$\underset{(\mathrm{ml} / \mathrm{l})}{\mathrm{CH}_{4} / \text { total gas } 48 \mathrm{~h}}$} \\
\hline & $6 \mathrm{~h}$ & $24 \mathrm{~h}$ & $48 \mathrm{~h}$ & & \\
\hline P. purpureophoides & $12.6^{\mathrm{a}}$ & $54.1^{\mathrm{a}}$ & $71.2^{\mathrm{a}}$ & $11.0^{\mathrm{a}}$ & $154^{\mathrm{A}}$ \\
\hline G. sepium & $9.3^{\mathrm{c}}$ & $43.6^{\text {cde }}$ & $64.0^{\mathrm{cd}}$ & $8.4^{\mathrm{ab}}$ & $131^{\mathrm{AB}}$ \\
\hline A. mangium & $7.3^{\mathrm{cd}}$ & $37.6^{\mathrm{ef}}$ & $61.3^{\mathrm{e}}$ & $6.2^{\mathrm{b}}$ & $101^{\mathrm{B}}$ \\
\hline L. leucocephala & $10.3^{\mathrm{b}}$ & $50.9^{\mathrm{ab}}$ & $66.3^{\mathrm{de}}$ & $7.6^{b}$ & $114^{\mathrm{B}}$ \\
\hline A. catecú & $6.9^{\mathrm{d}}$ & $33.3^{\mathrm{f}}$ & $69.5^{\mathrm{e}}$ & $7.6^{\mathrm{b}}$ & $129^{\mathrm{AB}}$ \\
\hline D. intortum & $12.1^{\mathrm{a}}$ & $49.6^{\mathrm{abc}}$ & $68.3^{\mathrm{b}}$ & $8.3^{\mathrm{ab}}$ & $121^{\mathrm{B}}$ \\
\hline C. sinensis & $6.8^{\mathrm{d}}$ & $40.3^{\mathrm{de}}$ & $60.5^{\mathrm{e}}$ & $7.0^{\mathrm{b}}$ & $115^{\mathrm{B}}$ \\
\hline C. calothyrsus & $11.1^{\mathrm{ab}}$ & $45.3^{\mathrm{bcd}}$ & $64.8^{\mathrm{c}}$ & $7.5^{\mathrm{b}}$ & $115^{\mathrm{B}}$ \\
\hline SEM & 0.52 & 1.54 & 0.67 & 0.56 & 9.15 \\
\hline $\mathrm{P}$ & $<0.001$ & $<0.001$ & $<0.001$ & $<0.001$ & 0.03 \\
\hline
\end{tabular}

Means in the same column followed by different letters are different $\left({ }^{\mathrm{A}-\mathrm{B}} \mathrm{P}<0.05 ;{ }^{\mathrm{a}-\mathrm{f}} \mathrm{P}<0.01\right)$

\section{Fermentation Characteristics}

The $\mathrm{pH}$ value, concentrations of $\mathrm{NH}_{3}-\mathrm{N}$ and VFA in the medium incubation are present in Table 3. The $\mathrm{pH}$ value in medium incubation was not significantly $(\mathrm{P}>0.05)$ different among treatments. Concentration of $\mathrm{NH}_{3}-\mathrm{N}$ significantly $(\mathrm{P}<0.05)$ increased in grass substrate with addition of extract of L. leucocephala as compared to control. Addition of extract of $G$. sepium, A. mangium, A. catechu, $C$. sinensis and C. calothyrsus in grass substrate decreased $(\mathrm{P}<0.001)$ total VFA concentration. Extracts of $G$. sepium, A. catechu and $C$. sinensis increased $(\mathrm{P}<0.001)$ proportion of acetate compared to control, whereas A. mangium and $C$. sinensis extracts reduced $(\mathrm{P}<0.001)$ proportion of propionate. Acetate:propionate ratio was highest in A. mangium and lowest in A. catechu extracts.

\section{In vitro Nutrient Degradability}

In vitro $\mathrm{OM}$ and $\mathrm{NDF}$ degradability of grass substrate with addition of tannin extracts is presented Table 4. Addition of L. leucochepala, C. sinensis and $C$. calothyrsus extracts to grass substrate decreased $(\mathrm{P}<0.001)$ IVOMD, whereas IVNDFD was decreased $(\mathrm{P}<0.001)$ by addition of A. mangium, L. leucocephala, A.catechu, D. intortum, C. sinensis and C. calothyrsus extracts as compared to control.

\section{Relationships between Tannin Content and Fermentation Variables}

The correlations between total tannin, condensed tannin and fermentation variables are in Table 5. There was a negative correlation between total tannin and the gas production at 6 , 24 and $48 \mathrm{~h}$ of incubation and $\mathrm{CH}_{4}$ production, indicating that as total tannin concentration increased, the gas and $\mathrm{CH}_{4}$ production decreased. Total tannin concentration had closer correlation with $\mathrm{CH}_{4}$ and $\mathrm{CH}_{4} /$ total gas production than condensed tannin concentration. There was negative correlation between total tannin content and both IVOMD and IVNDFD.

\section{Discussion}

The total tannin content in A. mangium was comparable to that value reported by Jayanegara et al. (2011), but condensed tannin content was lower than value of $42 \mathrm{~g} / \mathrm{kg} \mathrm{DM}$ as reported by Jayanegara et al.(2011) Concentration of total tannin in $D$. intortum was lower than in Desmodium intortum (Getachew et al., 2000). Concentration of condensed tannin in $L$. 
Table 3. The $\mathrm{pH}$, Concentrations of $\mathrm{NH}_{3}-\mathrm{N}$ and VFA in the Medium Incubation After $48 \mathrm{~h}$ of in vitro Incubation of $P$. purpureophoides Alone or with Addition of Plant Extracts

\begin{tabular}{|c|c|c|c|c|c|c|c|}
\hline & $\mathrm{pH}$ & $\begin{array}{c}\mathrm{NH}_{3}-\mathrm{N} \\
(\mathrm{mg} / 100 \mathrm{ml})\end{array}$ & $(\mathrm{mmol} / \mathrm{l})$ & $\begin{array}{c}\text { Acetate } \\
\text { (C2) } \\
(\mathrm{mol} / 100 \\
\mathrm{mol})\end{array}$ & $\begin{array}{l}\text { Propionate } \\
\text { (C3) } \\
(\mathrm{mol} / 100 \\
\mathrm{mol})\end{array}$ & $\begin{array}{c}(\mathrm{mol} / 100 \\
\mathrm{mol})\end{array}$ & $\mathrm{C} 2 / \mathrm{C} 3$ \\
\hline P. purpureophoides & 6.53 & $19.5^{\mathrm{BC}}$ & $139.2^{\mathrm{a}}$ & $71.0^{\mathrm{d}}$ & $15.9^{\mathrm{ab}}$ & $13.1^{\mathrm{a}}$ & $4.5^{\mathrm{cd}}$ \\
\hline G. sepium & 6.53 & $22.2^{\mathrm{C}}$ & $111.5^{\mathrm{b}}$ & $75.8^{\mathrm{abc}}$ & $14.2^{\mathrm{bc}}$ & $10.0^{\mathrm{abc}}$ & $5.4^{\mathrm{ab}}$ \\
\hline A. mangium & 6.54 & $21.2^{\mathrm{ABC}}$ & $88.5^{\mathrm{d}}$ & $76.7^{\mathrm{ab}}$ & $13.2^{\mathrm{c}}$ & $10.1^{\mathrm{abc}}$ & $5.8^{\mathrm{a}}$ \\
\hline L. leucocephala & 6.51 & $25.4^{\mathrm{A}}$ & $137.9^{\mathrm{a}}$ & $75.0^{\mathrm{abc}}$ & $15.6^{\mathrm{ab}}$ & $9.3^{\mathrm{bc}}$ & $4.8^{\mathrm{bcd}}$ \\
\hline A. catecú & 6.50 & $17.2^{\mathrm{BC}}$ & $87.9^{\mathrm{d}}$ & $73.8^{\mathrm{c}}$ & $17.0^{\mathrm{a}}$ & $9.2^{\mathrm{bc}}$ & $4.3^{\mathrm{d}}$ \\
\hline D. intortum & 6.48 & $22.6^{\mathrm{AB}}$ & $128.9^{\mathrm{a}}$ & $76.0^{\mathrm{abc}}$ & $17.0^{\mathrm{a}}$ & $7.1^{\mathrm{c}}$ & $4.5^{\mathrm{cd}}$ \\
\hline C. sinensis & 6.50 & $19.4^{\mathrm{ABC}}$ & $97.7^{\mathrm{cd}}$ & $74.3^{\mathrm{c}}$ & $14.4^{\mathrm{c}}$ & $11.3^{\mathrm{ab}}$ & $5.2^{\mathrm{abc}}$ \\
\hline C. calothyrsus & 6.53 & $19.3^{\mathrm{ABC}}$ & $103.3^{\mathrm{bc}}$ & $77.2^{\mathrm{a}}$ & $15.7^{\mathrm{ab}}$ & $7.1^{\mathrm{c}}$ & $4.9^{\mathrm{bcd}}$ \\
\hline SEM & 0.01 & 1.54 & 2.69 & 0.63 & 0.53 & 0.73 & 0.17 \\
\hline$P$ & 0.11 & 0.04 & $<0.001$ & $<0.001$ & $<0.001$ & $<0.001$ & $<0.001$ \\
\hline
\end{tabular}

Table 4. The IVOMD and IVNDFD after $48 \mathrm{~h}$ of Incubation of $P$. purpureophoides Alone or with Addition of Plant Extracts

\begin{tabular}{lcc}
\hline & $\begin{array}{c}\text { IVOMD } \\
(\mathrm{g} / \mathrm{kg})\end{array}$ & $\begin{array}{c}\text { IVNDFD } \\
(\mathrm{g} / \mathrm{kg})\end{array}$ \\
\hline $\begin{array}{l}\text { p. } \\
\text { purpureophoides }\end{array}$ & $606^{\mathrm{a}}$ & $336^{\mathrm{a}}$ \\
G. sepium & $588^{\mathrm{abc}}$ & $309^{\mathrm{a}}$ \\
A. mangium & $594^{\mathrm{ab}}$ & $222^{\mathrm{bc}}$ \\
L. leucocephala & $562^{\mathrm{c}}$ & $260^{\mathrm{b}}$ \\
A. catechu & $589^{\mathrm{abc}}$ & $189^{\mathrm{c}}$ \\
D. intortum & $575^{\mathrm{abc}}$ & $207^{\mathrm{c}}$ \\
C. sinensis & $560^{\mathrm{c}}$ & $187^{\mathrm{c}}$ \\
C. calothyrsus & $484^{\mathrm{d}}$ & $180^{\mathrm{c}}$ \\
SEM & 0.74 & 10.1 \\
P & $<0.001$ & $<0.001$ \\
\hline
\end{tabular}

Means in the same column followed by different letters are different $\left({ }^{\mathrm{A}-\mathrm{B}} \mathrm{P}<0.05 ;{ }^{\mathrm{a}-\mathrm{P}} \mathrm{P}<0.01\right)$ leucocephala and C. calothyrsus was lower than values of 76 and $240 \mathrm{~g} / \mathrm{kg} \mathrm{DM}$, respectively (Tiemann et al., 2008). Different of plant nutrients content in this study as compared to previous study could be due to difference in location of sample source and plants maturity.

Higher gas production with addition of plant extract could be due to the presence of higher of soluble sugar from these extract. In previous studies of Śliwiński et al. (2002); Patra et al. (2010), increasing gas production by plant extracts that contain phenol or saponin caused by increasing soluble sugar from these plant extract.

No differences in $\mathrm{pH}$ values obtained in the present study, consistent with previous studies of Śliwiński et al. (2002); Oliviera et al.(2007); Animut et al. (2008) who found that $\mathrm{H}$ was not changed by addition of tannin in both sheep and cattle rumens.

Tannin has beneficial effect on protection on dietary protein in the rumen and subsequently enhancement of amino acid absorption and utilization by the ruminant animal (Waghorn et al., 1994). McSweeney et al. (2001) revealed that tannin has ability to bind protein by forming hydrogen bonds between the phenolic sub-units of 
Table 5. Coefficient of Correlation $(r)$ Between Total Tannin, Condensed Tannin Contents and Gas Production, Fermentation Characteristics, in vitro Nutrients Degradability

\begin{tabular}{lcc}
\hline \multicolumn{1}{c}{ Variables } & Total Tannin & $\begin{array}{c}\text { Condensed } \\
\text { Tannin }\end{array}$ \\
\hline Gas 6 h & $-0.63^{* * *}$ & $0.70^{* * *}$ \\
Gas 24 h & $-0.61^{* *}$ & $0.60^{* *}$ \\
Gas 48 h & $-0.72^{* *}$ & $0.67^{* *}$ \\
$\mathrm{CH}_{4}$ & $-0.79^{* * *}$ & $-0.37^{\mathrm{ns}}$ \\
$\mathrm{CH}_{4} /$ total gas & $-0.66^{* * *}$ & $-0.12^{\mathrm{ns}}$ \\
Total VFA & $-0.65^{* * *}$ & $-0.53^{*}$ \\
$\mathrm{pH}$ & $0.10^{\mathrm{ns}}$ & $0.41^{\mathrm{ns}}$ \\
$\mathrm{C} 2$ & $0.56^{* *}$ & $-0.15^{\mathrm{ns}}$ \\
$\mathrm{C} 3$ & $-0.30^{\mathrm{ns}}$ & $-0.35^{\mathrm{ns}}$ \\
$\mathrm{C} 4$ & $-0.32^{\mathrm{ns}}$ & $0.43^{*}$ \\
$\mathrm{C} 2 / \mathrm{C} 3$ & $0.41^{*}$ & $0.33^{* *}$ \\
$\mathrm{NH}{ }_{3} \mathrm{~N}$ & $-0.04^{\mathrm{ns}}$ & $-0.17^{\mathrm{ns}}$ \\
IVOMD & $-0.40^{*}$ & $0.21^{\mathrm{ns}}$ \\
IVNDFD & $-0.21^{\mathrm{ns}}$ & $0.17^{\mathrm{ns}}$ \\
\hline
\end{tabular}

ns: not significant $(\mathrm{P}>0.05) ;{ }^{*}(\mathrm{P}<0.05)$;

${ }^{* *}(\mathrm{P}<0.01) ;{ }^{* * *}(\mathrm{P}<0.001)$

the polymer and the carbonyl groups of peptides of the protein. In vivo study, Min et al. (2005) suggested that the action of condensed tannin in forages markedly reduced both growth and population of proteolytic bacterial. However, the extent of positive or negative effects of tannins may vary depending on the type and level of tannins in plants and their biological activity (Getachew et al., 2000). Relatively higher concentration ammonia- $\mathrm{N}$ in the medium incubation with addition of extract of G. sepium, A. mangium, L. leucochepala, A. catechu and D. intortum could be due to higher crude protein content in those plants or tannin concentration is lower than minimum concentration needed to produce maximum inhibition of proteolysis.

The inhibition of methanogenesis has long been considered from nutritional aspects, and more recently from the perspectives on greenhouse gas emissions. In the previous studies by Śliwiński et al. (2002); Patra et al. (2006);
Patra et al. (2010); Rodríguez et al. (2011) who reported that $\mathrm{CH}_{4}$ production reduced by addition of plant extract containing tannin. In contrast, Beauchemin et al. (2007) described that supplementing a forage-based diet with quebracho tannin extract failed to reduce $\mathrm{CH}_{4}$ production from growing cattle. The same result has been reported by Oliviera et al. (2007) that feeding sorghum silage containing high or low concentrations of tannin did not affect nutrient digestibility and $\mathrm{CH}_{4}$ production in cattle. However, effect of tannin on methanogenesis depends on the source, type and dose of tannins (Patra et al., 2006). In this study, relative to control, addition $1.2 \mathrm{ml}$ extract of $A$. mangium, $L$. leucocephala, A. catechu, $C$. sinensis or $C$. calothyrsus decreased $\mathrm{CH}_{4}$ production by 43.6, $30.9, \quad 30.9, \quad 36.3$ and $31.8 \%$, respectively. Decreased $\mathrm{CH}_{4}$ production in this study, however might be related to decreasing of fibre degradation which is shown by high correlation coefficient value between $\mathrm{CH}_{4}$ production and NDF degradability $(r=0.61 ; P<0.01)$ (result not shown). This result was supported by previous study of Estermann et al. (2002) that there was a strong relationship between $\mathrm{CH}_{4}$ production and digestible NDF for cows and calves. Bhatta et al. (2009) concluded that tannins suppress methanogenesis by reducing methanogenic populations in the rumen either directly or by reducing the protozoal population, thereby reducing methanogens symbiotically associated with the protozoal population. Tavendale et al. (2005) revealed that condensed tannin reduce $\mathrm{CH}_{4}$ production could be due to indirect effect by reduced hydrogen production as result of reduced feed degradability, and by direct inhibitory effect on methanogens. A high correlation $(r=-0.79$, $\mathrm{P}<0.001)$ between total tannin concentration and $\mathrm{CH}_{4}$ production in this study (Table 5) was agreed with previous studies of Jayanegara et al. (2009, 2011); Hariadi and Santoso (2010) that found $r$ values $-0.60,-0.66$ and -0.76 , respectively. A similar observation was found by Bhatta et al. (2009) that total tannin had close correlation with $\mathrm{CH}_{4}$ output ( $r=-0.97$ ). In our study, IVNDFD in substrate with addition of $L$. leucocephala, A. catechu, D. intortum, $C$. sinensis or $C$. calothyrsus extracts was significantly lower than control. This finding agrees with previous study of Bhatta et al. (2009) who found that tannin significantly suppressed bacteria population, through a direct effect (Koike and Kobayashi, 2009) and by reducing nutrient availability 
(Sallam et al., 2010). In addition, tannin could reduce fibre digestion by complexing with lignocellulose and preventing microbial digestion or by directly inhibiting cellulolytic microorganism or both (McSweeney et al., 2001). In our results, IVOMD decreased ranged from 7.3 to $20.1 \%$ when addition of $L$. leucocephala, $C$. sinensis or $C$. calothyrsus extract to $P$. purpurophoides substrate. Similar result has been reported by Patra et al. (2006) that addition of extract of plants containing tannin reduced IVDMD and IVOMD by about $7 \%$ in comparison to control. Hess et al. (2003) also reported that tannins from $C$. calothyrsus may cause significant shifts in rumen microbial populations, especially a reduced total number of cellulolytic bacteria, which could have contributed to lower OM degradation.

\section{CONCLUSION}

Plant extracts from A. mangium, $L$. leucocephala, A. catechu, $C$. sinensis and $C$. calothyrsus have potential to be used as rumen manipulator in order to reduce $\mathrm{CH}_{4}$ production in ruminants. Among plant extracts, A. mangium had the strongest effect on in vitro $\mathrm{CH}_{4}$ production. The mode of action tannin on methanogenesis might be partially attributed to reduce fibre degradability.

\section{ACKNOWLEDGMENT}

This study was funded by the Directorate General of Higher Education, Ministry of National Education of Indonesia (Contract No. 262/SP2H/PP/DP2M/V/2009).

\section{REFERENCES}

Animut, G., R. Puchala, A.L. Goetsch, A.K. Patra, T. Sahlu, V.H. Varel and J. Wells. 2008. Methane emissions by goats consuming different sources of condensed tannins. Anim. Feed Sci. Technol. 144:228-241.

AOAC. 1990. Official Methods of Analysis. 15 ${ }^{\text {th }}$ ed. Association of Official Analytical Chemist. Arlington. VA. USA.

Beauchemin, K.A., S.M. McGinn, T.F. Martinez and T.A. McAllister. 2007. Use of condensed tannin extract from quebracho trees to reduce methane emissions from cattle. J. Anim. Sci. 85:1990-1996.

Bhatta, R., Y. Uyeno, K. Tajima, A. Takenaka, Y.
Yabumoto, I. Nonaka, O. Enishi and M. Kurihara. 2009. Difference in the nature of tannins on in vitro ruminal methane and volatile fatty acid production and on methanogenic archaea and protozoal populations. J. Dairy Sci. 92:5512-5522.

Chaney, A.L. and E.P. Marbach. 1962. Modified reagents for determination of urea and ammonia. Clin. Chem. 8:130-132.

Estermann, B.L., F. Sutter, P.O. Schlegel, D. Erdin, H.R. Wettstein and M. Kreuzer. 2002. Effect of calf age and dam breed on intake, energy expenditure, and excretion of nitrogen, phosphorus, and methane of beef cows with calves. J. Anim. Sci. 80:11241134.

Getachew, G., H.P.S. Makkar and K. Becker. 2000. Effect of polyethylene glycol on in vitro degradability of nitrogen and microbial protein synthesis from tannin-rich browse and herbaceous legumes. Br. J. Nutr. 84:7383.

Hariadi, B.T. and B. Santoso. 2010. Evaluation of tropical plants containing tannin on in vitro methanogenesis and fermentation parameters using rumen fluid. J. Sci. Food Agric. 90:456-461.

Hess, H.D., L.M. Monsalve, C.E. Lascano, C.E. Carulla, T.E. D'iaz and M. Kreuzer. 2003. Supplementation of a tropical grass diet with forage legumes and Sapindus saponaria fruits: effects on in vitro ruminal nitrogen turnover and methanogenesis. Aust. J. Agric. Res. 54:703-713.

Jayanegara, A., N. Togtokhbayar, H.P.S. Makkar and K. Becker. 2009. Tannins determined by various methods as predictors of methane production reduction potential of plants by an in vitro fermentation system. Anim. Feed Sci. Technol. 150:230-237.

Jayanegara, A., E. Wina, C.R. Soliva, S. Marquardt, M. Kreuzer and F. Leiber. 2011. Dependence of forage quality and methanogenic potential of tropical plants on their phenolic fractions as determined by principal component analysis. Anim. Feed Sci. Technol. 163:231-243.

Johnson, K.A. and D.E. Johnson. 1995. Methane emissions from cattle. J. Anim. Sci. 73: 2483-2492.

Koike, S., and Y. Kobayashi. 2009. Fibrolytic rumen bacteria: their ecology and functions. Asian-Austral J. Anim. Sci. 22:131-138.

Makkar, H.P.S. 2003. Quantification of Tannins in 
Tree and Shrub Foliage - A Laboratory Manual. Joint FAO/IAEA, Division of Nuclear Techniques in Food and Agriculture. Kluwer Academic Publisher, Dordrecht, The Netherlands.

Makkar, H.P.S., M. Blümmel and K. Becker. 1995. In vitro effects of and interactions between tannins and saponins and fate of tannins in the rumen. J. Sci. Food Agric. 69:481-493.

McSweeney, C.S., B. Palmer, D.M. McNeill and D.O. Krause. 2001. Microbial interactions with tannins: nutritional consequences for ruminants. Anim. Feed Sci. Technol 91:8393.

Menke, K.H. and H. Steingass. 1998. Estimation of the energetic feed value obtained from chemical analysis and in vitro gas production using rumen fluid. Anim. Res. Develop. 28:7-55.

Min, B.R., G.T. Atwwod, W.C. McNabb, A.L. Molan and T.N. Barry. 2005. The effect of condensed tannin from Lotus corniculatus on the proteolytic activities and growth of rumen bacteria. Anim. Feed Sci. Technol. 121:45-48.

Moss, A.R. 1993. Methane Global Warming and Production by Animals. Chalcombe Publications, Canterbury, p.105.

Oliveira, S.G., T.T. Berchielli, M.S. Pedreira, O. Primavesi, R. Frighetto and M.A. Lima. 2007. Effect of tannin levels in sorghum silage and concentrate supplementation on apparent digestibility and methane emission in beef cattle. Anim. Feed Sci. Technol. 135:236-248.

Patra, A.K., D.N. Kamra and N. Agarwal. 2010. Effects of extracts of spices on rumen methanogenesis, enzyme activities and fermentation of feeds in vitro. J. Sci. Food Agric. 90:511-520.

Patra, A.K., D.N. Kamra and N. Agarwal. 2006. Effect of plant extracts on in vitro methanogenesis, enzyme activities and fermentation of feed in rumen liquor of buffalo. Anim. Feed Sci. Technol. 128:276291.

Rodríguez, R, Britos, A., Rodríguez-Romero, N, Fondevila, M. 2011. Effect of plant extracts from several tanniferous browse legumes on in vitro microbial fermentation of the tropical grass Pennisetum purpureum. Anim. Feed Sci. Technol. 168:188-195.

Russell, J.B. and J.L. Rychlik. 2001. Factors that alter rumen microbial ecology. Sci. 292:1119-1122.

Sallam, S.M.A., I.C.S. Bueno, P.B. Godoy, E.F. Nozella, D.M.S.S. Vitti and A.L. Abdalla. 2010. Ruminal fermentation of tannins bioactivity of some browses using a semiautomated gas production technique. Trop. Subtrop. Agroecosyst. 12:1-10.

Sirohi, N.K., N. Pandey, N. Goel, B. Singh, M. Mohini, P. Pandey and P.P. Chaudhry. 2009. Microbial activity and methanogenesis as affected by plant secondary metabolites in different pant extracts. Int. J. Environ. Sci. Eng. 1:52-58.

Śliwiński, B.J., M. Kreuzer, H.R. Wettstein and A. Machmüller. 2002. Rumen fermentation and nitrogen balance of lambs fed diets containing plant extracts rich in tannins and saponins, and associated emissions of nitrogen and methane. Arch. Anim. Nutr. 56:379-392.

Tavendale, M.H., M.P.Meagher, D. Pacheco, N. Walker, G.T. Attwood and S. Sivakumaran. 2005. Methane production from in vitro incubations with Lotus penduculatus and Medigo sativa, and effects of extractable condensed tannin fractions on methanogenesis. Anim. Feed Sci. Technol. 123-124:403-419.

Tiemann, T.T., P. Avila, G. Ramirez, C.E. Lascano, M. Kreuzer and H.D Hess. 2008. In vitro ruminal fermentation of tanniniferous tropical plants: Plant-specific tannin effects and counteracting efficiency of PEG. Anim. Feed Sci. Technol. 146:222-241.

Tilley, J.M. and R.A. Terry. 1963. A two stage technique for the in vitro digestion of forage crops. J. Brit. Grassl. Soc. 18:104-111.

Van Soest, P.J., J.B. Robertson and B.A. Lewis. 1991. Methods for dietary fiber, neutral detergent fiber, and nonstarch polysaccharides in relation to animal nutrition. J. Dairy Sci. 74:3583-3597.

Waghorn, G.C., I.D. Shelton, W.C. McNabb and S.N. McCutcheon. 1994. Effect of condensed tannins in Lotus pedunculatus on its nutritive value for sheep. 2. Nitrogenous aspects. J. Agric. Sci. 123:09-119. 